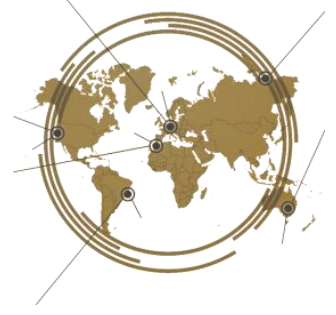

\title{
Investigating learning outcome based on a model of English teaching of Indonesian elementary students
}

\author{
Eny Syatriana*, Erwin Akib \\ English Education, Faculty of Teacher Training and Education, Universitas Muhammadiyah Makassar
}

This research aim of this study is to develop a model of teaching English for Indonesian elementary students. This developmental research consisted of five key procedures: analysis of need, model design, development, implementation, and evaluation. In the model development, two treatments were conducted to test the model. In the evaluation, a pre-test and post-test were administered to see the effectiveness of the model and the instructional materials in enhancing the English achievement of the students. The subject consisted of three school headmasters, three English teachers, and the fourth graders of three elementary schools in Makassar city. The teaching model consisting of four main stages: pre-activity, presentation, practice, and evaluation considers three main aspects: the language skill, language performance, and pedagogic aspects. The result indicates that the English teaching model is successful in enhancing the students' achievement in English and learning interest. In its form, the teaching model is flexible; it helps teacher write instructional materials, write lesson plans, teach, and analyze the teaching and learning process. The standards in the field support the model and the teaching of students.

Keywords: Teaching model, research and development, English achievement, elementary school students

\section{OPEN ACCESS}

ISSN 25033492 (online)

${ }^{\star}$ Correspondence:

Eny Syatriana

enysatriana@unismuh.ac.id

Received: 15th December 2020 Accepted: 12 th September 2021 Published: 12th September 2021

Citation:

Syatriana, E. and Erwin, A. (2021).

Investigating learning outcome based on a model of English teaching of Indonesian elementary students.

J. Eng. Educ. Society. 6:2.

doi:10.21070/jees.v6i2.1110

\section{INTRODUCTION}

In 2018 National examination questions in Indonesia started using Higher Order Thinking Skills (HOTS), a derivative of learning methods that Benjamin Bloom ignited through the theory of "Bloom's Taxonomy". Indonesian elementary school teacher has to do a lot with implementing it. Schools will develop syllabuses for each subject, and teaching and learning process lesson plan. The implementation of education is important for creating the smart and human generation. (Training \& Tidar, 2019) suggest that Indonesia's education objectives are to increase the ability of students.

Kirkpatrick (2016) stated the materials produced by the teachers, school head masters, and school commission in a teacher forum supervised by the school's educational stakeholders. The school curriculum enables the schools to build their own ability and teachers to articulate their learning goals. In this case a lot of changes are given to regions and schools to chances and improve different educational implementations based on the ability, situation and need of the region and the learning condition of the students. 
The curriculum requires teachers to be able to design syllabus write lesson plans, write instructional materials, use appropriate teaching technique or methods, and to develop models of teaching and learning effectively. The English learning outcome of the national assessment needs improvements at any educational level in Indonesia. Ellis and van Aart (2013) asserted that academic, culture, and university services are the major considerations in studying abroad. The academic concerns professors, courses delivered in foreign language, and instructional methods employed. The culture, on the other hand, includes the location of the city in which the university resides, and its atmosphere. Then, the university services involve help desk, counseling, accommodation and assimilation activities.

Research performed by the International Students Assessment System (PISA) and the Progress in the International Reading Literacy Survey (PIRLS) revealed that reading comprehension of Indonesian elementary education students in the lowest rank globally. PISA 2015 announced that reading comprehension of Indonesian students of elementary education was very low. The program ranked Indonesia 62ndout of 72 countries observed; PISA 2018 ranked Indonesia 74th out of 79 countries; PISA 2019 ranked Indonesia 72nd out of 77 countries; PISA 2019 ranked Indonesia indicated that the average scale score 396 (2015) of Indonesian, 371 (2018) of Indonesia score and 396 (2019) of Indonesian rating was 4th grade was 481 average was 500, slightly lower Indonesia's ranking. The achievement of Indonesian elementary education students reading English needs development.

Thus this study focus on developing a model of teaching English for elementary students, since this study is developmental study consisted of five main procedures: need analysis, model design, development, implementation, and evaluation. In the model development, two treatments were conducted to test the model.

This program was designed to assess the students' academic performance on average in each region. PISA is coordinated by OED (The International Coorperation and Development Organization). Mathematics, Science, and Reading Ability were tested. (OECD, 2013) claimed that many students, especially disadvantages, hold lower ambitions than would be expected given their academic achievement. On average across OECD countries, only seven in ten high-achieving disadvantaged students reported that they expect to complete tertiary education, while nine in ten high achieving advantaged students reported. Nation has a different number of samples; the OECD estimates that there are 600,000 students from 79 countries studied worldwide at PISA. Taking exam questions in Indonesia so far, he said, have levels of difficulty below PISA which is already focused on HOTS. It is because the founding OECD countries (the body holding PISA) have adopted the Bloom taxonomy scheme in their own right.

However the Indonesian curriculum does not apply the program at all, except for national exams. According to data from the PISA assessment, it has been shown that the reading comprehension of Indonesian students is weak in other research findings (Syatriana, 1998; Mardiana, 1993;
Hamra \& Syatriana, 2010; Hamra, 2012). The low achievement results from several factors: teachers, students, parents, learning environment, methods for teaching and learning, teaching media. The affective factors: mood, desire, behaviors influence the achievement in English, Critical thinking has been described on a general level as a collection of capabilities or cognitive skills related to logical analysis and argument assessment (Hamra, 2012). The attitude of students towards a language will influence the achievement of the language. (Syatriana, 2016), readers are required to convey the central message of the text suggesting that "if we really want to encourage positive reading attitudes or at least minimize negative attitudes (feelings), we need to be mindful of the present attitude of the students." Attitude is the general feeling and the focus is in the specific field of the feeling. It is a really disturbing feeling. It is a positive attitude towards someone or something.

Baș \& Bas (2012) claimed that confidence in reading affect students' reading comprehension. Reading has been described in a variety of ways to explain the process of what happens when one reads and how one comprehends a text. The importance of the interest of the reader in fostering the desire to read encouraging and guiding the reading comprehension. The importance of the interest of the reader in fostering the desire to read encouraging and guiding the reading." On the other hand, the reading process may also improve the read interest of the reader. The interest is a tendency of the soul that helps the realization of an action or behavior, expression or statement, and a person's reaction or participation to something or a particular activity that can arouse pleasure. Reading interest influences the reading comprehension of students.

Noortyani (2018) claimed to trigger students' reading interest, reading activity should be designed in a favorable way, not in the sense of utilitarian reading for examination or score, so the love of reading can be instilled gradually. (Kirkpatrick, 2016) stated in academic settings, from secondary to postgraduate instruction, second language students face mainly academic settings, from secondary to postgraduate instruction, second language students face many challenges, ranging from the need for a large academically oriented vocabulary to the ability to communicate, is one of the importance of reader's interest in promoting ability to read and directing reading." On the other hand, teaching and learning process of reading can also develop the reading interest of the students. In some modern schools, effective reading leads to the effective learning, developing interest in learning should enjoy priority, children should be provided with various kinds of modern facilities in order to create a relaxing, interesting, active and real language learning environment (Melendy, 2008), For students, habit of learning is started from a motivated thing to do for example habit of finding main ideas and details in reading.

Increasing student motivation is a way of increasing the interest and achievement the problem certainly must receive attention from language researchers considering the negative 
impact it highly brings to the learning outcomes (Mantasiah, Yusri, \& Jufri, 2019) since motivation is very important in learning, different efforts should be created especially in designing instructional materials and applying appropriate teaching strategies. Good instructional materials and teaching strategies implemented by teachers can influence the learning achievement and motivation of students.

In implementing the curriculum center, schools must develop their own school curriculum by specifying the school' educational goals, structure and the content, schedule, and syllabus for each subject. Modeling and instructional materials should be prepared based on the characteristics of school and students in order to meet the objective of this subject.

English is a foreign language in Indonesia, and it should be taught according to the teaching rules of a foreign language. Teaching English as a foreign language is different from teaching Indonesian as a first language. In Indonesia, for many Indonesian students. English can be the second, third, or fourth language. The lack of English speaking outside of the classroom makes EFL teachers more demanding. Successful teaching of English is closely related to the teachers instructional materials, the lesson plan prepared and implement.

It is believed that the language output or skills (listening, speaking, reading, and writing) and language competence are affected by several factors, such as learning motivation, the use of teaching technique, classroom engagement, intellectual awareness of students, instructional content, assessment, teacher involvement in teaching, etc. These are the learning environments which the teachers can monitor. Those were considered by this research as significant factors in design of teaching model to improve student learning outcome.

\section{Research Questions}

The description above originates some research questions:

- What kind of teaching model is sufficient to boost English achievement for Indonesian elementary school students?

- What is the effectiveness of the teaching model? How does the teaching model work?

- What is the students' interest in using that model?

\section{METHODS}

\section{Research Methodology}

This developmental research consisted of five steps in its creation: study, design, creation implementation, and evaluation (formative and summative evaluations) The researcher believes that using literature as a resource in ELT tool, may enhance the reading literature which is one of the best ways to encourage the writer in the learners (Tasneen, 2010).

\section{Subject}

The subject consisted of 90 elementary school students (ES) and three elementary school teachers from three elementary schools in Makassar in Academic year 2018/2019.

\section{Procedure}

Analysis of the needs as an integral part of evaluative review of English content, primarily textbooks, requires giving sufficient attention in all English language learning contexts. (Rashidi \& Kehtarfard, 2014).

\section{Treatment}

Instructional resources based on the teaching model were structured to see the model's usefulness for treatment purposes. Two tests were conducted to determine the model's the primary aim of the first treatment was to review the content, instructional prototype, consistency and team work and to enhance the process of teaching and learning. The second treatment was performed to see the students' actual effectiveness of the model and the learning effect, and what value the students' had in applying the model. The changes were related to the model development by action testing approach in the first and second treatment, and the learning behavior of the students was monitored and improved in the model development process.

\section{Instrument}

The research instruments consisted of reading test, questionnaire, evaluation, and review of focus group discussion. Using concise and inferential statistics quantitative data was analyzed. The motivation of the students' has been qualitatively analyzed. Documentation such as the school curriculum, competence level, basic skills, syllabus, and the lesson plans were addressed in terms of the content.

The instructional design guided of the methods, the quality of the presentation in formative assessment: listening, speaking, reading, and writing, linguistic skills and performance, teaching process. The method for making use the language determined the collection, graduation, presentation, and repetition (Nunn \& Toms, 2009), said efforts were limited in sand could not be part sections and unable to show expressions in terms of the model design. Observations were performed to see the teaching result, a reading test was conducted to see reading achievement of the students, and an interest questionnaire was conducted to explore the use the teaching model use.

\section{RESULTS AND DISCUSSION}

\section{Need Analysis}

Survey through interview and observation with the fourth year students suggested that the ability to listen, speak, read, and write was far from what they expected (Sönmez, 2019), define the purpose of the needs analysis is to identify the target language teaching/ learning needs in order to design an effective curriculum. The program requires them to be able to speak English, but most of them could not speak English. Most of them were unable to explain their school, listen to a very clear summary of their class, read with understanding of certain sentences, and phrases, and write good sentences or very short paragraphs. 
On the other hand, they wanted to speak English, listen to simple detail about their classroom in English, read about their classroom's simple explanation and write very simple sentences. Students need to develop the language skills (listening, speaking, reading, and writing).

Survey through deep discussion with the English teachers showed that the students need further language skills related improvements. There issue was due to key factors: (1) instructional reading materials did not agree with the curriculum, (and (2) the English learning interest of the students was low. Furthermore, the elementary English teachers lacked socialization and workshop on the curriculum implementation. The instructional materials did not include the themes or subjects, and certain roles did not with the curriculum.

Observations conducted at the three schools were shown that the teacher teaching methods have been monotonous. Monotonous teaching did not improve the students' interest in learning and learning outcomes. Too much talking dominated the teaching of the teachers. Current motivated strategies were neglected so that the students were boring and noisy. Most of the instructional materials did not go with the curriculum. The syllabuses and lesson plans were not prepared well so that they need improvements in relation to the material development.

The educational national standard is based on the definition of the competency level and the basic competences of English as a local subject at elementary school. The skill covers four main skills: listening, speaking, reading, and writing. Curriculum-based English plays a central role in in the student academic, social, and emotional development, and offers strong support for learning a subject in school. Students should be able to understand themselves, their culture, and the other cultures through English at school. Additionally learning English lets students communicate some ideas or emotion, engage in a group and use their basic analytical and creative skill.

English is a language used in both the spoken and written modes of communication. Communicating involves knowing the written forms, communicating facts, emotion, ideas or opinion while at the same time being able to use them to e grow science, technology, and culture. In other words, in the four abilities communication is the ability to address and understand the written and the spoken language: listening, speaking, reading, and writing. The four skills are used to build community-based discourse.

Thus, the English teaching is directed toward ability growth, so the graduates can communicate in English. Students with an educational level are able to use a language to serve their everyday lives, such as reading newspaper, documents or books; students with an information level are able to access knowledge or language skills: students with epistemic level are able to communicate their knowledge. The aim of English teaching at elementary school is to allow students to reach the usable level they are able to communicate in the simple spoken and written forms of English in their everyday lives at school and at home, Exposing students with great deal of English can allow them to better understanding target language (Sukirmiyadi, 2018). They should be aware about the importance of English in the global competition. English for communication at elementary school develops the four language skills.

\section{English Subject at Elementary Schools}

School teacher or English teachers teach the English subject at the high school. Many English teachers at elementary schools in Makassar graduated from university with an English department bachelor degree. Elementary schools offer English as a local subject because English is related to knowledge and science development. Most textbooks in Indonesian libraries and new scientific findings from different fields of study were written in English. English as an international language is taught from elementary schools to universities. Learning English include understanding native speaker culture, making many world mates ad expanding their global awareness. (Shah-Wundenberg, Wyse, \& Chaplain, 2013) Comprehension encompasses abilities to recognize words promptly and efficiently, develop and use a wide range of recognition vocabulary, engage a variety of strategic processes and underlying cognitive skills, interpret and evaluate texts matching reader targets and English at the three elementary schools. Many English teachers were given workshops to introduce the curriculum, but some did not.

\section{English Syllabus}

The teachers are often required also to write their own instructional material, but in factual most all of them are not able to write their own instructional materials. They are planning to choose from different publishers. A model of teaching at the elementary school was developed based on the focus group discussion among the elementary school teachers. The teaching model was based on the national curriculum and whole physical response concept. The instructional materials for elementary school students were designed in relation to need identification of the materials, exploration of the need, contextualization of the materials, pedagogical realization of the materials, material production, and the use of the materials (Hamra \& Syatriana, 2012).

\section{Lesson Plan}

The lesson plans are developed by teachers based on the prepared syllabus consisting of competence standard, basic competence, and basic competency, objective result, instructional content, teaching procedure, teaching and learning process, and assessment. Before teaching English teachers are to prepare lesson plans and most English teachers are able to design the lesson plans, teachers must transform the basic skill into performance target and evaluate the teaching content, the teaching and learning cycle, and the students teaching and learning outcome assessment.

\section{The Analysis of the Instructional Materials}

The in deep conversation between the researchers and the teachers suggested that English students achievement required improvement in curriculum expectations; the procedures started from (1) the identification of required materials to solve learning problems face by the students. (2) Exploration of problem area of need in relation to what language competence, what meaning, what functions, and what skills need to be involved in instructional materials. 
(3) Contextualization of the instructional materials covered three levels of events: regional, national, and international. (4) Pedagogical aspects included the use of appropriate strategies. (5) The physical production of the materials involved the layout, typing, visual. (6) Material use by the students, materials need to be tried out to see the effectiveness of the model. (7) Evaluation of the instructional materials involved students, teachers, and the experts in this field. The teaching procedures of the model and their instructional materials were designed based on the national curriculum. The instructional design or teaching procedure is in the following:

\section{Pre-activities}

This stages need teacher and students participating in the teaching and learning process using the concept of physical responses. For example: Teacher: Ali, Come over here please. Clean the white board, and take your seat. Thank you. Student: you're welcome. The instructional materials in the presentation and practice sections should be learned outside of the classroom, before students come to the class. Thus, teachers ask students to learn the instructional materials before they come to the class (Hamra \& Syatriana, 2012), and this will help students communicate comfort ably withe ache other in the classroom teaching and learning process.

\section{Presentation}

In this stage the learners are introduced to the teaching materials. The talk includes feature, grammar, and the vocabulary. The teachers are expected to know what they are going to teach by presenting the instructional materials, and the students know what they will learn. Reading instructional material consists of personal and transactional conversations; very short texts about classroom, school, and home environments. By reading a lot, students can learn and gain abundant information (Agustiani, 2017). Students are expected to read or complete personal and transactional conversations and the very basic explanation. Students can write or complete both personal and transactional interaction and explain the classroom events and school home environments in a very specific way.

\section{Evaluation}

A formative assessment is a accompanied by each lesson unit to see the effectiveness of the teaching process and to improve consistency of the learning processes. Every semester has a summative evaluation to know the learning result for the students.

\section{The Teaching Model}

The learning model or map developed based on the need analysis through deep discussion between the researcher and the English teachers consists of concepts relevant to the teaching and learning process as shown in figure 1.

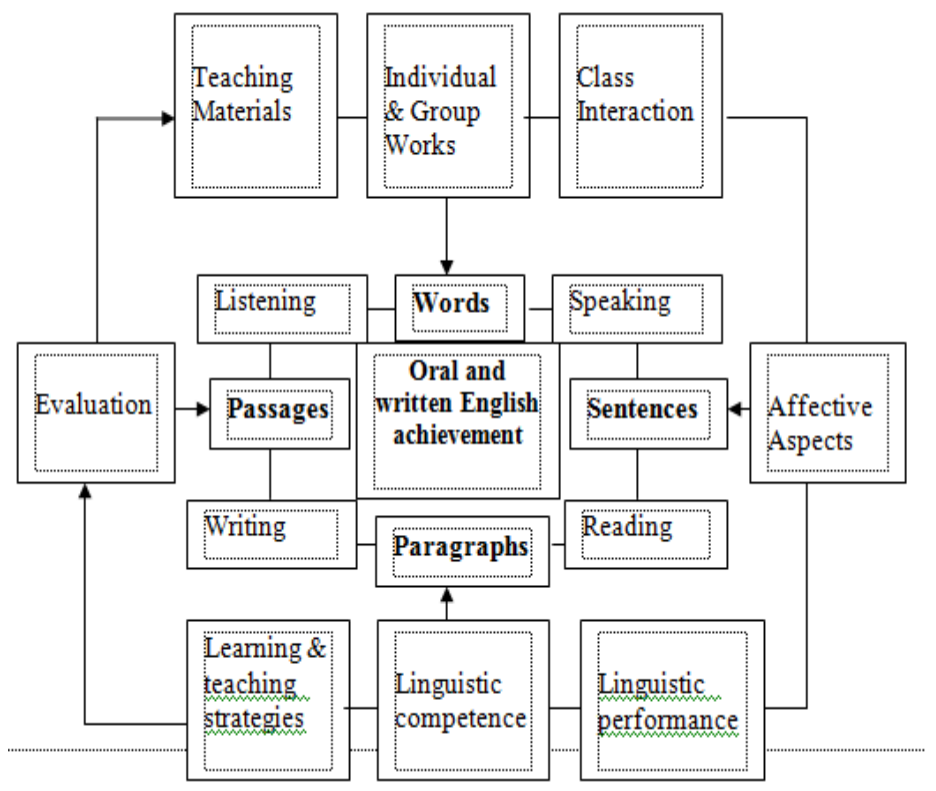

FIGURE 1 | The English teaching model of learning Process

The key goal of the teaching model is to achieve oral and written English in the middle of figure 1 (Hamra, 2010), stated the achievement of reading understanding as an goal of teaching and learning objective, the reading text, the cognitive \& affective dimensions, and the teaching environments in this teaching model: 1.The second square range involve listening, speaking, reading, and writing skills that students need to learn and the meaning of terms, phrases, paragraphs, and passages as the origin of the four competencies. The third square find (1) the teaching materials refer to language functions and subjects from the curriculum about class room, school, and home environments of the students (2); students and group participated in the teaching and learning process (3); class interactions in the forms of teacher-students, studentsstudents, and students-teacher (4); affective characteristic of student contribute to the learning engagement enthusiasm and motivation (5); linguistic success refer to ability to use the language or the functions of the language (6); linguistic competence relates to the knowledge of grammar, pronunciation, and spelling or the forms of the language (7); learning and teaching strategies especially relate in particular to the concepts of physical response which promotes the students' motivation and interest to learn English or perform the functions of the language, (8) evaluation refers to the formative and summative evaluations.

\section{The Tryout of the Teaching Model}

Model's tryout was performed into two steps of tryout. The first tryout involved one school and the second tryout involved three schools who join of the research view, the essential part of development process is aligning the material with student's needs and interest. The content should be planned and performed in a precise and firm manner because it represents whether or not it has been well developed and interest. 
1. The first tryout

Before the first tryout was conducted the teacher was given clarification of the teaching and learning process and the instructional materials were presented to the teacher based on the teaching model, competency level, basic competency, knowledge of total physical response, and school curriculum. The teachers were given the idea to present the instructional materials. Study testing was also conducted to know and at the same time to improve or update them. The tryout was initiated by giving the researcher a teaching example.
The first tryout of the model was performed at ES I, ES II, and ES III by conducting three tests using single one case study with design: $\mathrm{X} O \mathrm{O}(\mathrm{X}=$ teaching with instructional material based on the teaching model, $\mathrm{O}=$ Observation using a reading test with the analysis of SPSS version 13 . The result indicates that each of the tryout is improved (To 1 is compared to To 2 , tryout 2 is compared to To 3 , and To 1 is compared to To 3). This finding suggest that the use of the model in teaching English is not so effective statistically enhancing the students learning outcome. The detail data are in table 1.

TABLE 1 | The First Tryout

\begin{tabular}{|c|c|c|c|c|c|c|c|c|c|}
\hline \multirow{3}{*}{$\begin{array}{l}\text { The } \\
\text { empiric- } \\
\text { al tryout }\end{array}$} & \multicolumn{8}{|c|}{ Paired differences } & \multirow{3}{*}{$\begin{array}{l}\text { Sig. } \\
\text { (2-tail } \\
\text { ed }\end{array}$} \\
\hline & & & & Std Erron & $\begin{array}{l}95 \% \text { confidenc } \\
\text { the Difference }\end{array}$ & Interval of & & & \\
\hline & $\mathrm{N}$ & Mean & Std dev. & Mean & Lower & Upper & $\mathrm{T}$ & df & \\
\hline To 1 & 30 & 75.7188 & 31.17788 & 5.51152 & -16.17833 & 6.3033 & -896 & 29 & .377 \\
\hline To 2 & 30 & 80.6563 & & & & & & & \\
\hline To 2 & 30 & 80.6563 & 30.03734 & 5.30990 & -19.94462 & 1.70462 & -1.718 & 29 & .096 \\
\hline To 3 & 30 & 89.7813 & & & & & & & \\
\hline To 1 & 30 & 75.7188 & 27.39274 & 4.66567 & -2357810 & -4.54690 & -3.014 & 29 & .005 \\
\hline To 3 & 30 & 89.7813 & & & & & & & \\
\hline
\end{tabular}

Table 1 indicates that the average score of To $2(\mathrm{M}=$ $80.563)$ is higher than To $1(\mathrm{M}=75.7188)$, but it is not statistically different. The average score of To 3 ( $\mathrm{M}=$ $89.813)$ is higher than To $2(\mathrm{M}=80.6563)$, but it is not statistically different. The average score of To 3 ( $\mathrm{M}=$ $8.9813)$ is higher than To $1(M=75.188)$, and it is statistically different. The result indicates that hypothesized model is not completely effective in the small tryout, but it indicates improvement.

\section{The second tryout}

The second empirical tryout was administered at ES I, ES II, and ES III. The tryout was administered three times at each school with one group pretest-posttest design: O1 X $\mathrm{O} 2$. The result of the empirical tryout at each school is in table 2.

TABLE 2 | The Second Tryout Result at ES

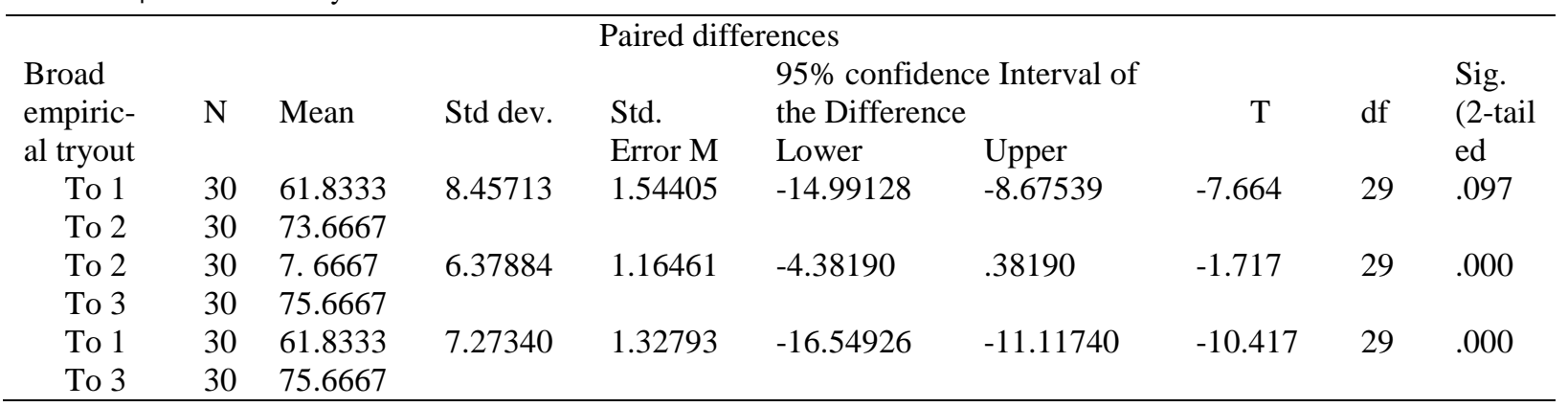

Table 2 indicates that the average score of To $2(\mathrm{M}=$ 73.6667) is higher than To $1(\mathrm{M}=618333)$, although it is not statistically different. The average score of To 3 ( $\mathrm{M}=$ 75.6667) is higher than the average score of To 2 ( $\mathrm{M}=$ 73.6667), and it is statistically different. The average score of To $3(M=75.6667)$ is higher than the average score of To $1(\mathrm{M}=61.8333)$, and it is statistically different. The result indicates that the hypothesized model is effective in this tryout.
Table 3 indicates that the average score of To $2(\mathrm{M}=$ $81.5000)$ is higher than the To $1(\mathrm{M}=7.3333)$, and it is statistically different. The average score of To $3(\mathrm{M}=87.3333)$ is higher than the average score of To $2(\mathrm{M}=81.50000)$, and it is statistically different. The average score of To $3(\mathrm{M}=87.3333)$ is higher than the average score of To $1(\mathrm{M}=78.3333)$, and it is statistically different. The result indicates that the hypothesized model is effective in the tryout. 
TABLE 3 | The Result of the Second Tryout at ES II

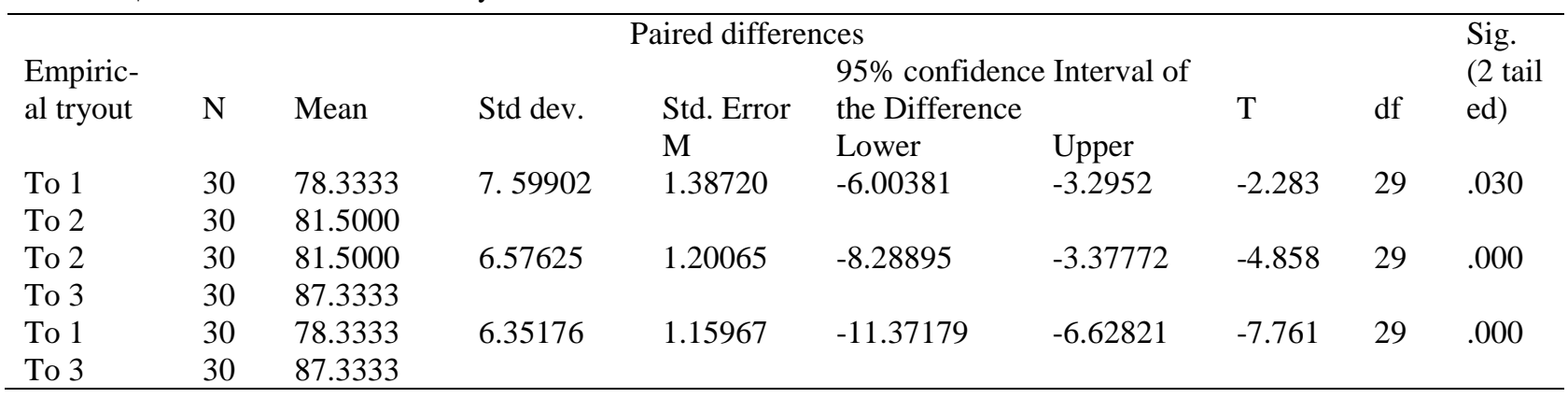

TABLE 4 | The Result of the Second Tryout at ES III

\begin{tabular}{|c|c|c|c|c|c|c|c|c|c|}
\hline \multirow{3}{*}{$\begin{array}{l}\text { The } \\
\text { empiric- } \\
\text { al tryout }\end{array}$} & \multicolumn{6}{|c|}{ Paired differences } & \multirow{3}{*}{$\mathrm{T}$} & \multirow{3}{*}{ df } & \multirow{3}{*}{$\begin{array}{l}\text { Sig.(2 } \\
\text {-tail } \\
\text { ed) }\end{array}$} \\
\hline & $\mathrm{N}$ & Mean & Std dev. & Std. & $\begin{array}{l}95 \% \text { confi } \\
\text { the Differ }\end{array}$ & Interval of & & & \\
\hline & & & & Error M & Lower & Upper & & & \\
\hline To 1 & 30 & 58.5000 & 11.47336 & 2.09474 & -14.78422 & -6.211578 & -5.013 & 29 & .000 \\
\hline To 2 & 30 & 69.0000 & & & & & & & \\
\hline To 2 & 30 & 69.0000 & 7.48370 & 1.36633 & -10.96113 & -5.37221 & -5.977 & 29 & .000 \\
\hline Tot 3 & 30 & 77.1667 & & & & & & & \\
\hline To 1 & 30 & 58.5000 & 10.98065 & 2.00478 & -22.76691 & -14.56642 & -9.311 & 29 & .000 \\
\hline To 3 & 30 & 77.1667 & & & & & & & \\
\hline
\end{tabular}

Table 4 indicates that the average score of To $2(\mathrm{M}=$ 69.0000) is higher than To $1(\mathrm{M}=58,5000)$, and it is statistically different. The average score of To $3(\mathrm{M}=$ 77.1667) is higher than To $2(\mathrm{M}=69.0000)$, and it is statistically different. The average score of To $3(\mathrm{M}=$ 77.1667) is higher than the average score of To 1 ( $\mathrm{M}=$ 58.5000), and it is statistically different. The result indicates that the hypothesized model is effective in the tryout.

\section{The Result of the Pretest and Posttest}

In addition to the model tryout, a pretest was conducted before the treatment and a posttest after the treatment at each school in order see the effectiveness of implementation of the teaching model. The result is in table 5 .

TABLE 5 | The Result of the pre-test and post-test

\begin{tabular}{|c|c|c|c|c|c|c|c|c|}
\hline \multirow[t]{2}{*}{ Tryout School } & & & & \multicolumn{2}{|c|}{$\begin{array}{l}95 \% \text { confidence interval of } \\
\text { the difference }\end{array}$} & & & $\begin{array}{l}\text { Sig. } \\
\text { (2-tail }\end{array}$ \\
\hline & $\mathrm{N}$ & Test & Mean & Lower & Upper & $\mathrm{T}$ & df & ed \\
\hline ES I & 30 & Pretest & 52.6667 & -27.92743 & -20.73924 & -13.847 & 29 & .000 \\
\hline & & Posttest & 77.0000 & & & & & \\
\hline ES II & 30 & Pretest & 66.3333 & -19.66249 & -13.67085 & -11.378 & 29 & .000 \\
\hline & & Posttest & 83.0000 & & & & & \\
\hline ES III & 30 & Pretest & 56.33 & -26.40690 & -20.59310 & -16.534 & 29 & .000 \\
\hline & & Posttest & 79.8333 & & & & & \\
\hline
\end{tabular}

Table 5 indicates that the average score of the posttest at ES I $(M=77.0000)$ is higher than the pretest $(M=52.6667)$, and it is statistically different. The average score of the posttest at ES II $(\mathrm{M}=83.0000)$ is higher than the pretest ( $\mathrm{M}$ $=66.3333$ ), it is statistically different. The average score of the posttest at ES III $(\mathrm{M}=79.8333)$ is better than the average of the pretest $(\mathrm{M}=56.33)$, and it is statistically different. This indicates that the hypothesized model is effective in its use in the teaching and learning process. The outcome of the model tryout toward the implementation in the teaching and learning process is in the following: Active, or experiential, teaching is a student-centered teaching method. It includes any technique that involves the students in the learning process and holds students responsible for their own learning. In the instructional design process, there are a lot of factors that should be taken into consideration. These factors are closely related to each other and affect each other to a certain extent. (Hackathorn, et. al, 2011) From an innovation point of view, active teaching techniques change the pace of the classroom, and are a 
creative way to increase students' involvement, motivation, excitement, attention and perceived helpfulness.

\section{The students' Interest toward the Teaching and Learning Process}

The Questionnaire of interest given to students consists of three aspects: (1) interest toward the English subject, (2) instructional materials, and (3) teachers' method in teaching. Nearly all of the students (97\%) were interested in the English subject, instructional materials given, and teachers' teaching method. (Issman, 2011) noted that in the instructional design process, there are a lot of factors that

TABLE 6 | The Main Teaching Procedure

Pre Activities/Command and Request

Every lesson starts with In this step instructional commands or request from the teacher to the students or from student to student, for instance: Teacher: Ali, come here please. Clean the and say the instructional whiteboard, close the door, materials; they need to and go to your seat. Student: explain the social functions Zaky, can you borrow me and grammatical structures your pen please. I forget my of the language.

pen at home. These are preactivities before students start their learning at school. In the pre-activity the students are also required to study the lesson outside the class before they come to their class should be taken into consideration. These factors are closely related to each other and affect each other to a certain extent. As the result in reading instructional material consists of personal and transactional conversations, very short texts about classroom, school, and home environments that should be considered to affect the interest of the students in the learning process to have global understanding

\section{The Instructional Design}

The main teaching procedures of the model include:

The following procedure of the result in reading instructional material consists of personal and transactional conversation as in the following table 6 :

\section{Practice of listening $\&$ speaking,} reading $\&$ writing with different

\section{strategies}

For examples: look, say, practice, Final judgment repeat, say it again please. conducted for each Listening and speaking skills are meeting to improve connected with integrated the teaching and strategies. Reading and writing are learning process connected with different integrated (formative strategies. Thus, each of the teaching steps has different teaching techniques that can lead students to construct/speak English independently. Question and answer, role play, say something, etc. are examples of strategies that can lead students to be independent speakers. Teachers facilitate the students to work in pair or in groups of 5 to seven students. evaluation) and summative evaluation after each semester to know the learning outcome of the students.
To summarize, the main teaching procedure which linked to the model design has been designed to meet the leaner needs of the learners, will promote and empower English Achievement.

\section{CONCLUSION}

English teaching at Makassar elementary school as a local subject needs improvement in instructional materials and teaching strategies. The teaching model which consists of four main procedures: pre-activity, presentation, practice, and evaluation considering the four main parts: the linguistic competence, linguistic performance, pedagogical aspects, and learning strategies in order to obtain good spoken and written English achievement at elementary schools. The teaching model is effective in improving the learning outcome of the students, helping elementary English teachers plan an appropriate instructional materials, conducting teaching and learning process, and reviewing the teaching and learning process. In the model implementation the students are interested in the teaching procedures conducted through the awareness of total physical response. The students are interested in the implementation of the teaching model and the instructional materials. The model also helps teachers to conduct teaching and learning process, 
will be based on the school curriculum, the purpose of material writing, and the applications of various learning strategies.

This teaching model is an innovative model that can be used by the English language teachers at elementary schools to teach and to develop instructional materials to enhance English skill in Indonesian schools as a local subject. It is expected that teachers in the teaching and learning process are expected to activate learning and to keep good teaching and learning phase should enable learning and maintain a good teaching and learning environment for the students to work. Teachers should monitor the activities of listening, speaking, reading, and writing condition that effect and the achievement of language. Effective teaching and learning motivates students to learn; thus teachers must pay attention to the students' affective factors in the teaching and learning process (Zhu \& Zhou, 2012). For the purpose of teaching and learning, instructional materials or course books for elementary school students are required (for the fourth, fifth, and sixth graders of elementary school) based on the teaching model. Implementing the model during the teaching and learning process increase the learning outcome of the students. The model design helps teacher to prepare the instructional materials, lesson plans, teaching and learning process, and learning assessment. Then this model recommendation is relevant to improve the instructional material based on theory of designing a course book as well in university level. The model proposes a balance relationship between the principles of pedagogy, linguistics and success. The students' Interest toward the Teaching and Learning Process as the highlight should be from innovative teachers, to link the transactional conversation in the implementation of English language teaching to boost English achievement of EFL Learners.

\section{ACKNOWLEDGEMENTS}

The researcher thanked the headmaster of SD Negeri Ikip Makassar, Headmaster of SD Mongisindi Makassar, 3) The Headmaster of SD Komp Mangkura, All English teacher in three separate elementary schools. Muhammdiyah University of Makassar. The Ristekdikti, higher education department for the financial support. The researchers likewise thank the reviewers of the Asian EFL Journal for the suggestions and input for this article.

\section{REFERENCES}

Agustiani, I. W. D. (2017). The correlation between students reading attitude and their reading comprehension achievement. English Community Journal. https://doi.org/10.32502/ecj.v1i2.764

Baş, G., \& Bas, G. (2012). Reading attitudes of high school students: An analysis from different variables. International Journal on New Trends in Education and Their Implications, 3(2), 47-58.
Retrieved from

http://ijonte.org/FileUpload/ks63207/File/04.bas.pdf

Ellis, H., \& Van Aart, J. (2013). Key influencers of international student satisfaction in Europe 2013. Study Portals.

Hackathorn, J., Solomon, E. D., Blankmeyer, K. L., Tennial, R. E., \& Garczynski, A. M. (2011). Learning by doing: An empirical study of active teaching techniques. The Journal of Effective Teaching, 11(2), $40-54$.

Hamra, A. (2010). Developing a model of teaching reading comprehension for EFL students. TEFLIN Journal, 21(1), 27-40.

https://doi.org/10.15639/teflinjournal.v21i1/27-40

Hamra, A., \& Syatriana, E. (2012). A model of reading teaching for university EFL students: Need analysis and model design. English Language Teaching. $5(10), 1-11$. https://doi.org/10.5539/elt.v5n10p1

Işman, A. (2011). Instructional design in education: New model. Turkish Online Journal of Educational Technology, 10(1), 136-142.

Kirkpatrick, A. (2016). The Journal of Asia TEFL. Journal of Asia TEFL, 13(1), v-vii. https://doi.org/10.18823/asiatefl.2016.13.1.1.i

Mantasiah, R., Yusri, \& Jufri. (2019). The role of bilingualism in increasing children's cognitive ability at primary school. Asian EFL Journal, 23(62), 42-55.

Mardiana, A. (2018). The Use of Directed Reading-Thinking Activity (DR-TA) strategy to improve reading comprehension ability at the tenth graders of SMK PGRI 1 Punggur in the academic year 2017/2018 (Doctoral dissertation, IAIN Metro).

Melendy, G. A. (2008). Motivating Writers: The power of choice. Asian EFL Journal, 10(3), 187-198. Retrieved from

http://search.proquest.com/docview/85671973?accou ntid=14548\%5Cnhttp://metadata.lib.hku.hk/hku?url_ ver $=$ Z39.88-

2004\&rft_val_fmt=info:ofi/fmt:kev:mtx:journal\&gen re $=$ article \&sid=ProQ:ProQ:llba\&atitle=Motivating+ Writers:+The+Power+of+Choice \& title $=$ Asian+EFL+ Jou

Noortyani, R. (2018). An exploratory study on students' reading interest development through independent reading-retelling activity. Arab World English Journal (AWEJ), 9(2), 108-117.

Nunn, R., \& Toms, C. (2009). The Asian ESP journal. The Asian ESP Journal, 5(2), 1-120.

OECD. (2013). PISA 2018 Results. Combined executive summaries. Journal of Chemical Information and Modeling, 53(9), 1689-1699. https://doi.org/10.1017/CBO9781107415324.004

Rashidi, N., \& Kehtarfard, R. (2014). A needs analysis approach to the evaluation of Iranian third-grade high school English textbook. SAGE Open. 4(3). https://doi.org/10.1177/2158244014551709 
Reflinda, R. R. (2017). The Effect of learning strategy and reading interest to the reading understanding ability of students of IAIN Bukit Tinggi. International Journal on Language, Research and Education Studies, 1(2), 226-239.

Robertson, P., \& Adamson, J. (2007). The Asian ESP journal. The Asian ESP Journal, 3(2).

Shah-Wundenberg, M., Wyse, D., \& Chaplain, R. (2013). Parents helping their children learn to read: The effectiveness of paired reading and hearing reading in a developing country context. Journal of Early Childhood Literacy, 13(4), 471-500. https://doi.org/10.1177/1468798412438067

Sönmez, H. (2019). An examination of needs analysis research in the language education process. International Journal of Education and Literacy Studies, 7(1), 8. https://doi.org/10.7575/aiac.ijels.v.7n.1p.8

Sukirmiyadi. (2018). Teaching English to young learners through Indonesian - translated songs. Journal of Physics: Conference Series, 953(1), 193-200. https://doi.org/10.1088/1742-6596/953/1/012236

Syatriana, E. (2016). Implementing a design model in teaching writing through reflection strategy for Indonesian EFL students. Asian EFL Journal, 2.

Syatriana, Eny, \& Akib, E. (2019). The effect of mapping instructional materials on EFL learners with different types of materials. International Journal of Humanities and Innovation (IJHI), 2(2), 20-24. https://doi.org/10.33750/ijhi.v2i2.37

Tasneen, W. (2010). Literary texts in the language classroom: A study of teachers' and students' views at international schools in Bangkok. Asian EFL Journal, 12(4), 173-187.

Training, T., \& Tidar, U. (2019). The Implementation of curriculum 2013 revision on lesson plans made by English teachers of SMAN 2 Magelang in School Year 2018 / 2019, 17-23.

Zhu, B., \& Zhou, Y. (2012). A Study on students' affective factors in junior high school English teaching. English Language Teaching, 5(7), 33-41.

https://www.kemdikbud.go.id/main/blog/2016/12/peringkatdan-capaian-pisa-indonesia-mengalami-peningkatan, retrieved 30 Maret 2020.

https://www.kompasiana.com/frncscnvt/5c1542ec677ffb3b5 33d6105/pisa-dan-literasi-indonesia, retrieved 30 Maret 2020
Conflict of Interest Statement: The authors declare that the research was conducted in the absence of any commercial or financial relationships that could be construed as a potential conflict of interest.

Copyright (C) 2021 Eny Syatriana and Akib Erwin. This is an open-access article distributed under the terms of the Creative Commons Attribution License (CC $B Y)$. The use, distribution or reproduction in other forums is permitted, provided the original author(s) and the copyright owner(s) are credited and that the original publication in this journal is cited, in accordance with accepted academic prac- tice. No use, distribution or reproduction is permitted which does not comply with these terms. 